\title{
QUALITY OF LIFE IN THE CITY, QUALITY OF URBAN LIFE OR WELL-BEING IN THE CITY: CONCEPTUALIZATION AND CASE STUDY
}

\author{
FRANTIŠEK MURGAŠ, MICHAL KLOBUČNÍK
}

Department of Geography, Faculty of Science, Humanities and Education, Technical University of Liberec, Studentská 2, 46117 Liberec, Czech Republic; e-mail: frantisek.murgas@tul.cz

Department of Human Geography and Demography, Faculty of Natural Sciences, Comenius University, Mlynská dolina, Ilkovičova 6, 84215 Bratislava 4, Slovak Republic; e-mail: michal.klobucnik@uniba.sk

\begin{abstract}
Murgaš F., Klobučník M.: Quality of life in the city, quality of urban life or well-being in the city: Conceptualization and case study. Ekológia (Bratislava), Vol. 37, No. 2, p. 183-200, 2018.

Quality of life research responds to the growth of urbanization in the world by increasing the focus on the quality of urban life; however, the dominant applied research tends to be without conceptualization of the quality of urban life. The aim of this paper is to answer the question whether the quality of urban life exists as an original, separate part of the concept of quality of life, or whether only the quality of life or the well-being of a certain city exists. The authors argue that the quality of urban life exists as an original category of quality of life and their beliefs are based on the fact that it can be measured separately. The quality of urban life is holistic, co-existing with the quality of life. The city from the point of view of quality of life research is a place, and the quality of urban life is the satisfaction with life in a city and the quality of place in it. This approach is applied to the quality of urban life and its measurement in the city of Liberec. The results are implications for policy-makers and urbanists.
\end{abstract}

Key words: quality of life, quality of urban life, well-being, quality of place, holistic approach, city of Liberec.

\section{Introduction}

Development at present, which is considered the late modern period, is manifested by increased complexity, multidimensionality and interdependence of social and economic processes. The development of cities in its qualitative and quantitative forms is one of the significant parts illustrating these processes. According to statistical data, today's global urban population has exceeded fifty percent; in Europe, it has reached seventy-four percent and in the Czech Republic, it was sixty-nine percent in 2015. Thus, the cities have become the drivers of social and economic development. The flip side of this development is the accompanying growth of the phenomena of social pathology, especially crime accompanied by an increase in mental disorders. Attention is therefore rightly dedicated to the growing cities or to the conurbation with millions of people in different parts of the world, although the di- 
chotomy urban-rural has not lost its justification (Ruiz, 2015). Over the past few years, there has been a rapidly growing city population in the countries of the Global South, while in big cities but also in smaller cities of the countries of the Global North, the qualitative aspect of their development dominates with a strong emphasis on ecology. This is illustrated by the attention paid to the quality of life of urban residents, to the environment in the cities and to the cities as centres of creativity (Landry, 2008). The number of measurements and charts of various aspects of the quality of life in the cities is increasing. Problems associated with urban sprawl pose a great challenge for scientists (Marans, 2012).

What are we talking about when we talk about the quality of life? It refers to the extremely complex and multi-dimensional concept of interrelated variables characterizing the idea of the good life and satisfaction with that, and how the life of an individual approaches this notion. If a human is to feel good and secure in life, they need to be engaged in things that lead them to some ideal - to a goal. In the Aristotelian thought conception this is called the final cause (causa finalis in Latin), through which not only the 'end of the work' (causa operis) but also the 'end of the agent' (finis operantis). This way, one then actualizes the endeavor for a 'good life' (Podzimek 2016: 1069). Success of its study is conditional on a multi-disciplinary approach and by accepting the fact that the quality of life is determined culturally and geographically. In connection with the cities, we examine the quality of urban life; as for terminology, we prefer the more often used term quality of urban life than the less frequently used term urban quality of life (Tiran, 2016). And what are we referring to when we talk about the quality of urban life? Does it differ from 'general' or the quality of life 'as a whole' for people who live in the city? If there is no difference, then for one and the same phenomenon, we use two different names and the quality of urban life and the quality of life of urban residents are synonymous notions. If there is a difference, it is necessary to explain what it is. The quality of life is holistic; it has two dimensions: well-being and quality of place. Therefore, if the quality of urban life exists, it must be holistic and also have these two dimensions.

Quality of urban life research began in the 1960s (Marans, Stimson, 2011). In 1986, the monograph Quality of Urban Life. Social, Psychological, and Physical Conditions (Frick et al., 1986) was edited by Dieter Frick. Investing Quality of Urban Life. Theory, Methods, and Empirical Research (Marans, Stimson, 2011) is a significant contemporary monograph focused on urban quality of life. In the 1980s, the study of the quality of urban life significantly enriched the development of urban geography and remained significant until the beginning of the 21st century. In urban geography, this development also contributed to developing the idea of 'useful knowledge' in the context of 'applied urban geography' (Pacione, 2003b). In the past, the attention was focused on the material conditions of the quality of urban life, especially living standards (Peil, 1984; Santos, Martins, 2007). At present, the research is oriented towards subjective and objective dimensions of the quality of urban life and their measurement (Marans, Stimson, 2011). Slovak and Czech geographers have paid a great attention to studying quality of urban life: Andráško (2006, 2007, 2016), Andráško et al. (2013), Ira (2005, 2015), Ira, Andráško (2008), Ira et al. (2005), Ira, Šuška (2006), Kladivo, Halás (2012), Rišová, Pouš (2018).

In scientific papers that are dedicated to dealing with the urban-rural dichotomy of quality of life, there is a frequent comparison of life satisfaction in the countryside and in cities. According to Sirgy (2012), in many European countries, Australia and Latin America, life in 
big cities is detrimental to life satisfaction, and on the contrary, rural life is beneficial to life satisfaction. In regards to the Czech Republic, Murgaš and Klobučník (2016a) have pointed out that the average quality of life in villages measured on Cantril's scale from 0 to 10 is almost the same (5.31) as in the cities (5.14), while the quality of urban life in the smallest towns is the lowest (4.60) and the highest in cities that have a population of over one hundred thousand inhabitants (6.38), which also includes the city of Liberec.

In relation to the quality of urban life, we can say that researchers focus on two different understandings of the city. In the first case, the basic level are districts and on a higher level is the city (Türkoğlu et al., 2011; Kladivo, Halas, 2012). According to Pacione (2003b), most of the geographic studies of quality of life are focused on the intra-urban level. In the second case, the basic level is a 'city as a whole', and a higher level is a region or a state. Specific works are those which are focused on the assessment of all settlements, i.e. villages and cities in the region (Marans, Kweon, 2011; Stimson et al., 2011) or across the country (Włodarczyk, 2015; Murgaš, Klobučník, 2016b).

For examining the quality of urban life, the attention is focused on large cities or metropolitan areas, and analyses of small or medium-sized cities with populations of up to one million inhabitants (Santos, Martins, 2007; Rezvani et al., 2013; Tiran, 2016). In our paper, we focused on the Czech city of Liberec with a population of 103,000 in 2016, making it the fifth largest city in the Czech Republic. The number of inhabitants in the city of Liberec increases as in only one regional city of the Czech Republic. (The population is also increasing in the capital city of Prague, but the growth is a result of immigrant origin.) The study "Quality of life in municipality of Liberec" (Murgaš, 2016a) has been carried out on the basis of an order placed by the Municipality of Liberec.

The aim of this paper is to answer the question whether there is a quality of urban life as the original, a separate part of the concept of quality of life or if quality of life, possibly the well-being, of a certain city exists. If the quality of urban life exists, it is necessary to outline its conceptualization and measurement. It would also be interesting to know what is the relationship between the quality of urban life in Liberec and the quality of life of its inhabitants. From the above it will be possible to draw implications for policy-makers and urban planners.

\section{Theoretical background and conceptualization}

Quality of life has a number of attributes - it is an elusive concept (Budowski et al., 2016), a shibboleth (Rapley, 2008), an umbrella concept. If we accept these claims, then quality of life cannot be conceptualized or measured. The claim that we do not know what a good life is - because for everyone it means something different - is a postmodern understanding of the quality of life. In contrast, according to Bradley (2015, vii), “well-being has always been a central notion in moral and political philosophy. It plays a role in determining the rightness of action."

We can hear quite often the statement that "often it is difficult to differentiate between the notions of quality of life, well-being, satisfaction, and happiness" (Marans, 2015: 48), or that these notions are considered to be synonyms. We do not agree with this characterization in our approach; rather we distinguish the quality of life, well-being and happiness (Marans, 
2012; Budowski et al., 2016). On the other hand, we value life satisfaction when we examine the quality of life. Therefore, we consider the notions of life satisfaction and well-being as synonyms.

Quality of urban life has been conceptualized by several authors (Izakovičová, 2005; Marans, Stimson, 2011b; Nuvolati, 2014; Marans, 2015; Izakovičová et al., 2017). According to Marans and Stimson (2011), the basis for the conceptualization of the quality of urban life is a holistic understanding of approaches that are focused on well-being and quality of place. The conceptualization of the quality of urban life is based on the following premises:

- Quality of life is holistic. It consists of two dimensions: subjective (well-being) and objective (quality of place) (Murgaš, Klobučník, 2016a). It has two levels - individual and societal.

- A reference point to which the concept of quality of life relates is the concept of the good life (Ferriss, 2010; Michalos, Robinson, 2012; Veenhoven, 2013), which is lived in a good place (Murgaš, 2016b).

- An important part of a good place in the quality of urban life is its ecological domain. Murgaš and Klobučník (2016) state that the correlation between the emission balance and the Quality of Life Index is 0.34 , which means a «moderate» correlation according to the verbal evaluation of the numerical values of the correlations (de Vaus, 2002).

- Quality of life as well as all the current concepts cannot be measured. What can be measured are the variables - the indicators. Well-being is measured by a questionnaire; the results are the primary variables. The quality of place is gleaned from statistical sources; the results are secondary variables.

- Even if well-being is the more important out of the two dimensions, it is not quality of life itself. The meaning of quality of life is 'over' well-being and quality of place, and they are its dimensions.

- Life satisfaction is what one assesses when answering the question of how to evaluate one's life as a whole. Well-being or ill-being is an expression of life satisfaction. Life satisfaction is the content of quality of life; its scale is long term.

- Happiness is short-lived emotional state in which a person can survive the greatest possible fulfilment of their expectations. When we measure life satisfaction on Cantril's scale from 0 to 10 , happiness refers to number 10. As the feeling of happiness fades away, then it translates to life satisfaction.

- The quality of urban life is a societal quality, where the key word is a place (Andrews, 2001; Marans, 2012; Murgaš, 2016b). The word 'urban ' focuses the notion of quality of life on the quality of life of people living in a certain place, that is, in the city. (Likewise, 'rural ' focuses on the quality of life of people living in rural areas.)

- Quality of life and quality of urban life are two notions, and each means something else. Quality of life is the quality of life of the individual, and it is secondary to where the individual lives, whether in the city or village. The quality of urban life in our particular city of Liberec expresses how the inhabitants of the city are satisfied with the life in Liberec and not how an inhabitant is 'generally' satisfied with life. Life satisfaction 'generally' is the quality of life, or its personal dimension.

- The quality of urban life in the city (the city N) is holistic and has two dimensions - life satisfaction of inhabitants of the city $\mathrm{N}$ and the quality of place in the city $\mathrm{N}$. 
- The city in terms of quality of life research is a place, and the quality of urban life is the satisfaction with life in the city and the quality of place in it. This is a key element of its conceptualization.

According to Murgaš (2016b), the quality of life is a good life, which is lived in a good place. Different opinions on the co-relation between prosperity and its influence on the good life exist (Murgaš, Böhm, 2015).

A good place is a place with high quality of external, tangible and intangible prerequisites of a good life. The quality of life of the individual meets with the quality of life of the community or the societal quality within it. The good life is associated with good company and on the contrary, creating a good society is the key to a good life. In terms of good life, Veenhoven states that the (2014: 5265) quality of life is "the degree to which a life meets various standards of the good life".

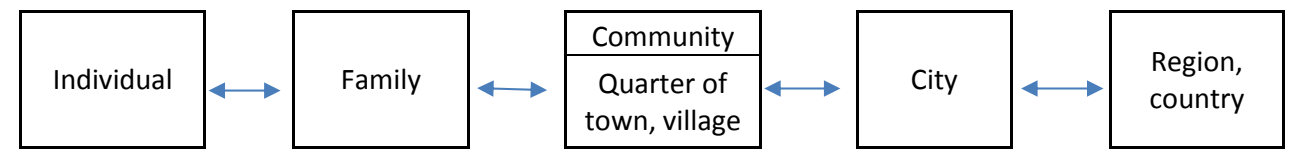

Fig. 1. Levels of quality of place.

The quality of place has five levels (Fig. 1). The dimension of well-being is more important for the quality of life on the individual, family and community level; the impact of the quality of place on well-being is small (Murgaš, Klobučník, 2016b). The dimensions of quality of place are more important for the quality of life on a city district or village, or at the region/ state level. The quality of life of the individual turns into societal quality of life and that is from the community, city, district or village level. The terms 'family' (micro-communities) and 'community' have social content, and the terms 'rural settlement' and 'city district 'have spatial content. It is natural that if the community lives in one city district, the terms 'community' and 'city district' are merged. From a social point of view, we divide larger and big cities into communities; from an urban point of view, we divide them into city districts.

Psatha et al. (2011) emphasize that the quality of urban life in terms of the societal quality of life cannot be considered as the average life quality of the city residents. It is caused by the fact that indicators on an individual level are not capable of being automatically transferred to a societal level; the reverse is also true. Nuvolati (2014: 6848) defines "the concept of quality of urban life regards the living conditions in urban areas and mainly in cities." This definition reduces the quality of urban life to the living conditions because of the absence of well-being. If the quality of life is a subjective assessment of one's own life lived in the spatially differentiated external environment, then the quality of urban life will be the subjective assessment of life satisfaction lived in a certain city and its quality of place.

In conceptualization of the quality of urban life besides its holistic determination, the search for an answer to the following questions will be important: (i) if the quality of urban life is the only one of the life quality categories (as it is in the research of quality of life of several age groups or in spatial, hierarchically organized units), or it is an original quality of 
life. Furthermore, the question (ii) of its differentiation from others arises, meaning the nonurban quality of life. If we accept the hypothesis, that the quality of urban life is the original quality of life, does it mean (iii) that it has its own dimensions?

Pacione (2003a) believes that the quality of urban life is the original quality of life. He considers that the dimension that is specific for it is social groups in the city. In our opinion, the answers to questions asked are the following:

i. The quality of urban life is the original quality of life; it exists together with the quality of life in any city or village. We derive its quality out of the fact that it is possible to ask the question: 'How satisfied are you with living in the city $\mathrm{N}$ in general?' and to measure the answers (Murgaš, 2016a). Besides that, it is also possible to ask the inhabitants of the city $\mathrm{N}$ the question, 'How satisfied are you with your life in general?' We quantify the answer to the first question 'well-being in the city $\mathrm{N}$ ' by answering the second question 'well-being generally'. It is natural, that on a regional or state level, only part of the respondents are the inhabitants of cities. But the division of population into urban and rural population is not important in the research of the societal quality of life.

ii. The differentiation of urban from non-urban means that rural quality of life is only semantic. From the content viewpoint, both qualities of life are two kinds of settlement and societal quality of life.

iii. The quality of urban life - in a certain city $\mathrm{N}$ - is equal in meaning to the quality of life (in case it is applied to a certain city), and therefore it is divided into dimensions. We will get the holistic quality of urban life in the city $\mathrm{N}$ by connecting the well-being of inhabitants in the city $\mathrm{N}$ and the quality of place in the city $\mathrm{N}$.

\section{Measurement and data}

There are several indicators used while measuring the quality of urban life (Psatha et al., 2011; Marans, 2015; Włodarczyk, 2015). Most of these variables are secondary data gathered from statistical surveys and they create the quality of space in a certain city. Murgaš and Klobučník (2016a) quantified the quality of life in all settlements, and also in cities in the Czech Republic, using indicators that make up the gold standard of quality of life. The fair values of the indicators were converted to a consistent range $<0-1>$. If we accept the need for a holistic understanding of the quality of urban life, we have to make two measurements: (i) satisfaction of inhabitants with life in the city - well-being and (ii) the quality of place.

As we have already mentioned, at the request of the Municipality of Liberec, the Technical University of Liberec, Department of Geography conducted a study "Quality of life in municipality of Liberec" (Murgaš, 2016a). The study was based on a questionnaire survey, which drew responses from 505 inhabitants of Liberec ( 210 men and 295 women). The research was conducted from May to June 2016. A question about the quality of life was a part of the questionnaire: How would you express satisfaction with your life? on a scale of 0 to 10 . Another issue was about the quality of urban life: How would you express satisfaction with life in Liberec? (possibilities for a response on a 5-point scale: very satisfied, satisfied, neither satisfied nor dissatisfied, dissatisfied and very dissatisfied). Liberec reached a 6.4 value on a scale of 0 to 10 from the aspect of quality of place (Murgaš, Klobučník, 2016a). 
All data from the questionnaires were grouped into a unitary database from which we created a pivot table. Using our method, we were able to obtain the necessary results - life satisfaction of the inhabitants of Liberec with life in the city and the quality of life of this city, both divided according to demographic characteristics (sex, age and education). We constructed overview charts for a better analysis of the obtained results from which we were able to make several conclusions. It should be noted that the quality of urban life in Liberec and the quality of life of the inhabitants of Liberec were analysed in relative numbers.

\section{Results}

In the first step, we constructed a hundred percent pie chart (Fig. 2). We assigned the following weight to the individual answers to questions concerning the quality of urban life on the 5-point scale: very satisfied (9 points), fairly satisfied (7 points), satisfied with some aspects, dissatisfied within others ( 5 points), fairly dissatisfied ( 3 points) and very dissatisfied ( 1 point). We used these points as a comprehensive analysis, when we compared the difference between optimal and gained points within the quality of urban life (9-7-5-3-1 point) and quality of life (Cantril's scale 0-10) according to sex, age and education. The optimal condition would occur if people were "very satisfied" within the question about satisfaction with the quality of urban life and at the same time, when asked to assess the quality of life, gave 10 or 9 points. It would be an ideal combination of the highest quality of urban life with the highest quality of life.

As shown in Fig. 2, the inhabitants of Liberec are very satisfied with the quality of urban life in the city; nearly four-fifths stated that they are very or fairly satisfied. The number of fairly dissatisfied is three percent; very dissatisfied respondents comprise not even one percent.

Comparing the quality of life by gender (Fig. 3) does not produce clear results. According to many authors, on the one hand, women report higher quality of life; on the other hand, there are no

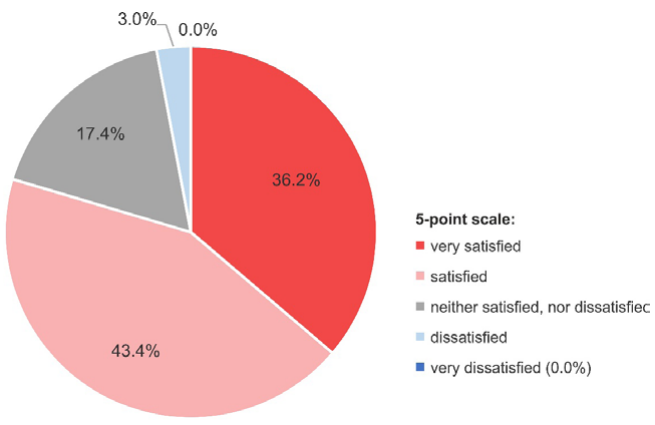

Fig. 2. Quality of urban life in Liberec.

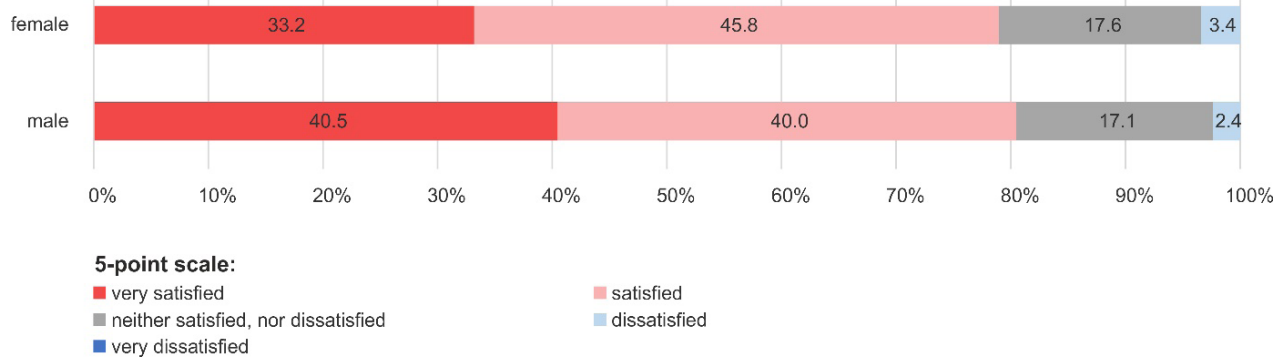

Fig. 3. The quality of urban life by gender. 
differences between men and women as per some other authors (Blatný, Šolcová, 2015). In our case, gender differences between men and women are in pentiles with the values very and fairly satisfied. About seven percent fewer women than men reported they are very satisfied, and six percent more women than men are fairly satisfied; the number of undecided is almost the same. Those responding that they are fairly dissatisfied is almost the same number as well. The difference between very or fairly satisfied men and women is small; 80.5 percent of men is slightly more than 79 percent of women.

According to Blatný and Šolcová (2015), the youngest and oldest age groups have a higher level of well-being, whereas people in the middle age have a lower level of well-being. This statement was not confirmed in the case of Liberec. As shown in Fig. 4, the quality of urban life increases with age. By age groups, the quality of urban life in the previous segmentation of women and men is differentiated much more. The most satisfied are the oldest inhabitants of Liberec aged 66 years and older, the value of more than forty percent in points «very satisfied ' is the highest among surveyed variables of gender, age and education. When we consider these points together with 'satisfaction 'in comparison with 'dissatisfaction ', the

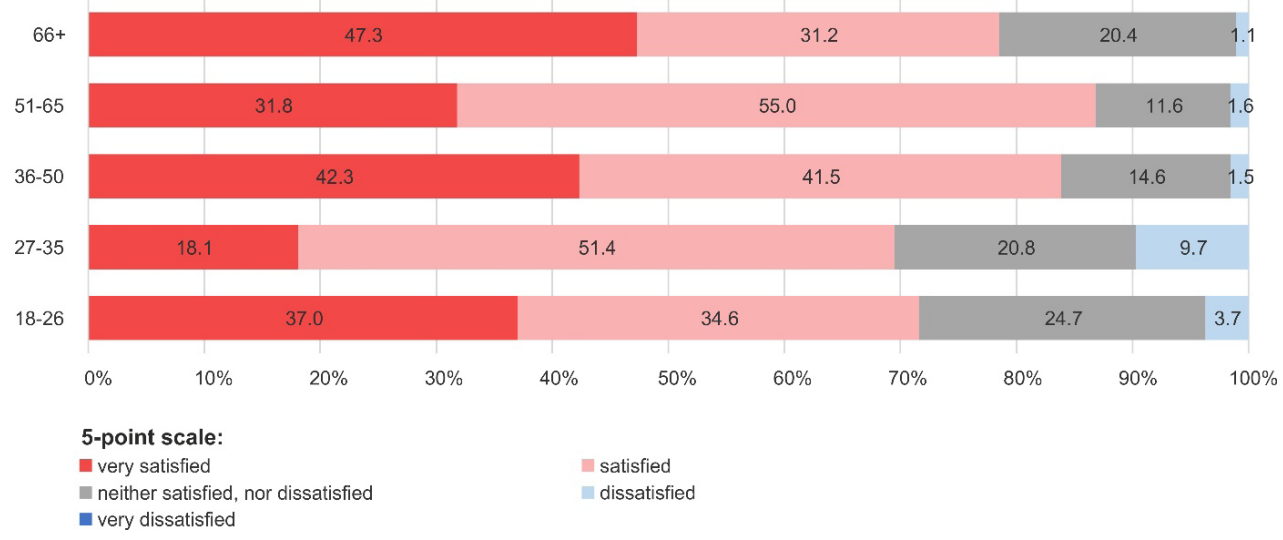

Fig. 4. Quality of urban life according to age groups.

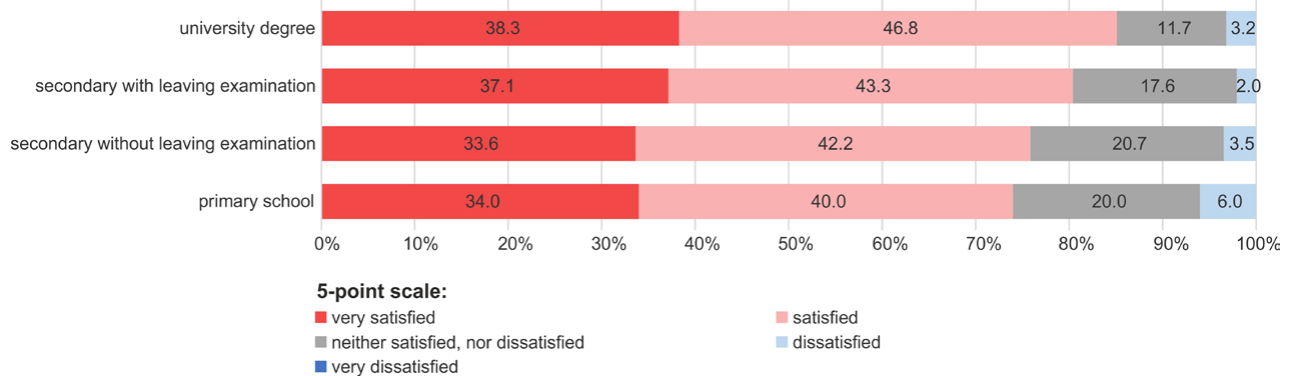

Fig. 5. Quality of urban life according to education. 
first dominated in the most remarkable ratio. The pentile 'mostly satisfied ' with the value of fifty percent in the age group of 51- to 65-year olds has the highest numerical value of all measurements of quality of urban life and the quality of life in Liberec. The least satisfied are the inhabitants of Liberec in the age group of 27-35 years; they also have the highest proportion in point 'dissatisfied ' out of the variables of gender, age, education.

According to Blatný and Šolcová (2015), several surveys point to the increase of wellbeing together with the increase of education. This finding was also confirmed in our paper (Fig. 5). The quality of urban life rises with gained education; however, the differences in various categories of education are not large.

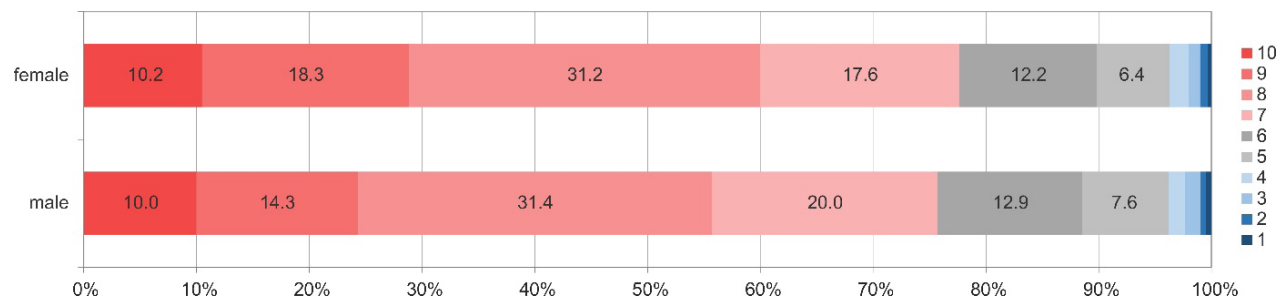

Fig. 6. Quality of life according to sex.

Note: There were no answers in the value 'zero' on a scale of $0-10$.

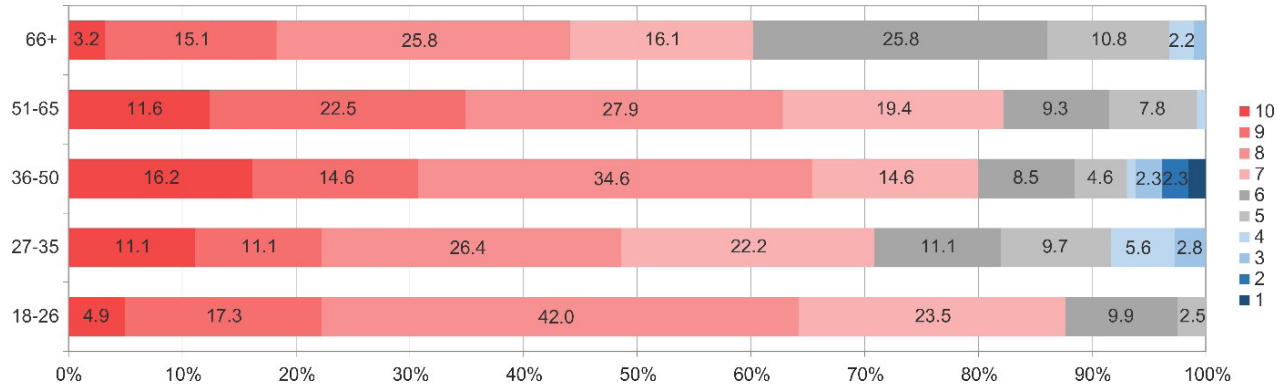

Fig. 7. Quality of life by age group.

Note: There were no answers in the value 'zero' on a scale of $0-10$.

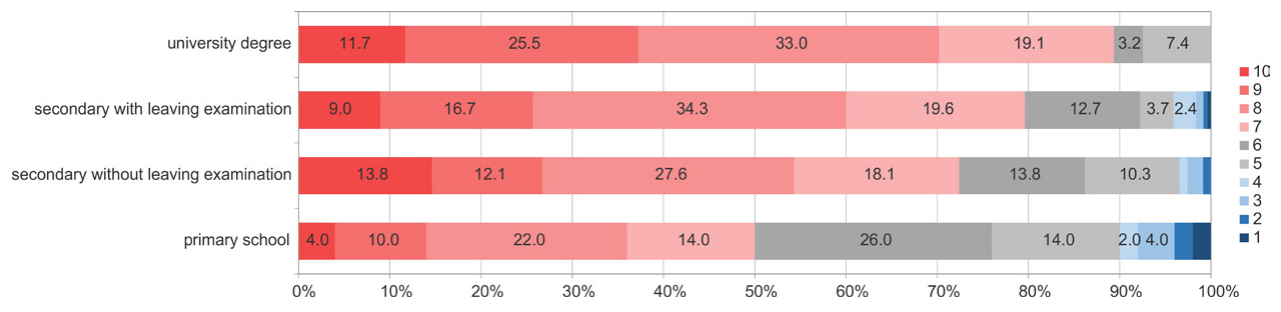

Fig. 8. Quality of life according to education.

Note: There were no answers in the value 'zero' on scale of $0-10$. 
$\mathrm{T} \mathrm{a} \mathrm{b} \mathrm{l} \mathrm{e} 1$. The Pearson correlation coefficient between the quality of urban life and quality of life.

\begin{tabular}{|l|l|c|c|c|}
\hline \multicolumn{2}{|c|}{ Sex } & Dwellers & Pearson's coefficient & Assessment $^{\text {a }}$ \\
\cline { 2 - 5 } & female & 295 & 0.2464 & small $^{\text {Age }}$ \\
\cline { 2 - 5 } & $66+$ & 210 & 0.3109 & medium \\
\cline { 2 - 5 } & $51-65$ & 129 & 0.2078 & small \\
\cline { 2 - 5 } & $36-50$ & 130 & 0.2470 & small \\
\cline { 2 - 5 } & $27-35$ & 72 & 0.4321 & medium \\
\cline { 2 - 5 } & $18-26$ & 81 & 0.0997 & medium \\
\hline \multirow{3}{*}{ Education } & university degree & 94 & 0.3262 & medium \\
\cline { 2 - 5 } & $\begin{array}{l}\text { secondary with exam } \\
\text { (most typically 4 years) }\end{array}$ & 245 & 0.3268 & small \\
\cline { 2 - 5 } & $\begin{array}{l}\text { secondary without exam } \\
\text { (most typically 4 years) }\end{array}$ & 116 & 0.2861 & small \\
\cline { 2 - 5 } & primary school & 50 & 0.2669 & small \\
\hline \multirow{5}{*}{ Total } & & 505 & 0.1120 & small \\
\hline
\end{tabular}

a'The word 'evaluation' was based on de Vaus (2002).

The quality of life, which is the answer to the question 'How satisfied are you with your life in general?' and for which we gave attributes 'generally' or 'as a whole' for clarity to distinguish the quality of urban life slightly differ or show no difference at all between women and men in Liberec within Cantril's scale. The satisfaction expressed by the value of 10, the highest within Cantril's scale that we consider to be happiness, was declared by ten percent of men and slightly more women. If we want to compare the quality of life and urban quality of life by gender, we need to convert Cantril's value to the 5-point scale value (9-7-5-3-1). The differences are significant, especially for men. In the point 'very satisfied ' within the quality of urban life, there are more than forty percent of men yet within the quality of life, only more than twenty-four percent of men. In the point 'satisfied 'within the quality of life, there is eleven percent more men than in the quality of urban life. In the point 'very satisfied ', within the quality of life, there are less women than in the quality of urban life, but the differences are smaller than for men. Overall, we can say that within the quality of life and quality of urban life, the share of very satisfied and satisfied men and women is nearly the same, around eighty percent (Fig. 6).

We can see a significant differentiation in the quality of life by age group (Fig. 7). A value of 10 in Cantril's scale was declared by a small percentage of the population of Liberec, in the youngest and oldest age range. In the other age ranges, value 10 was declared by a multiple times higher percentage. If we identify the value of 7-10 of Cantril's scale with the points very satisfied and satisfied, the highest quality of life is declared by the youngest population in the age group 18-26 years (87.7\%) and an older population in the age group 51-65 years $(81.4 \%)$. The lowest percentage of the highest quality of life is observed within the oldest inhabitants aged 66 or older $(60.2 \%)$. On the contrary, the lowest quality of life, value $0-3$, can be seen within the age groups 27-35 years and 35-50 years, while in this age group the lowest rating of 1 or 2 is declared. 
Within the quality of life according to education (Fig. 8), there is an expected increase from the population with basic education to inhabitants with university education. In our pentile scale, very and fairly satisfied represent almost ninety percent of the population with higher education and on the other hand, only fifty percent of the population with basic education. In this educational category, the most - up to ten percent - are fairly and very dissatisfied.

Together with the identification of the quality of urban life as the original quality of life, the question of its relationship to quality of life comes to the fore. We explored this relationship using previously used variables - gender, age and gained education. The findings are

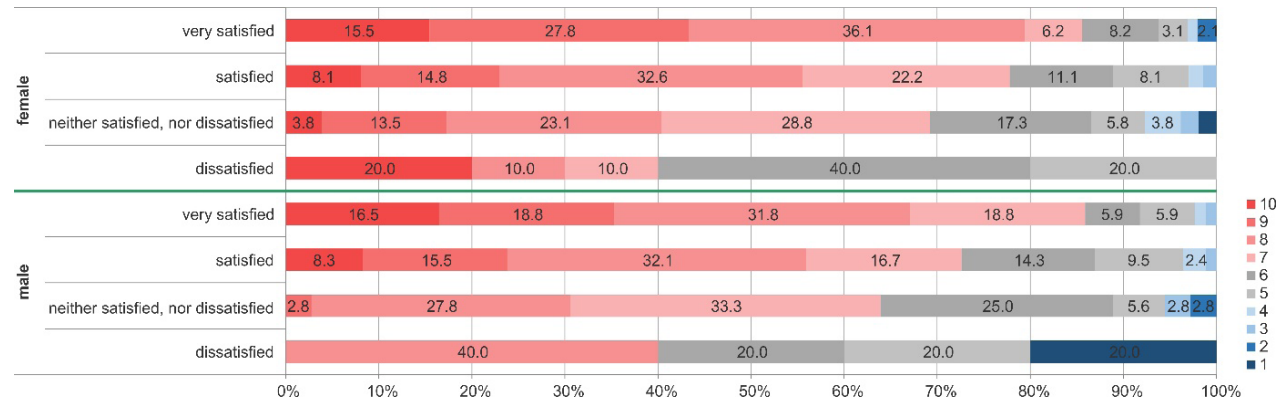

Fig. 9. Relation between quality of urban life and quality of life by gender.

Note: There were no answers in point 'very dissatisfied' as well as in value 'zero' on a scale from 0 to 10 for both men and women.

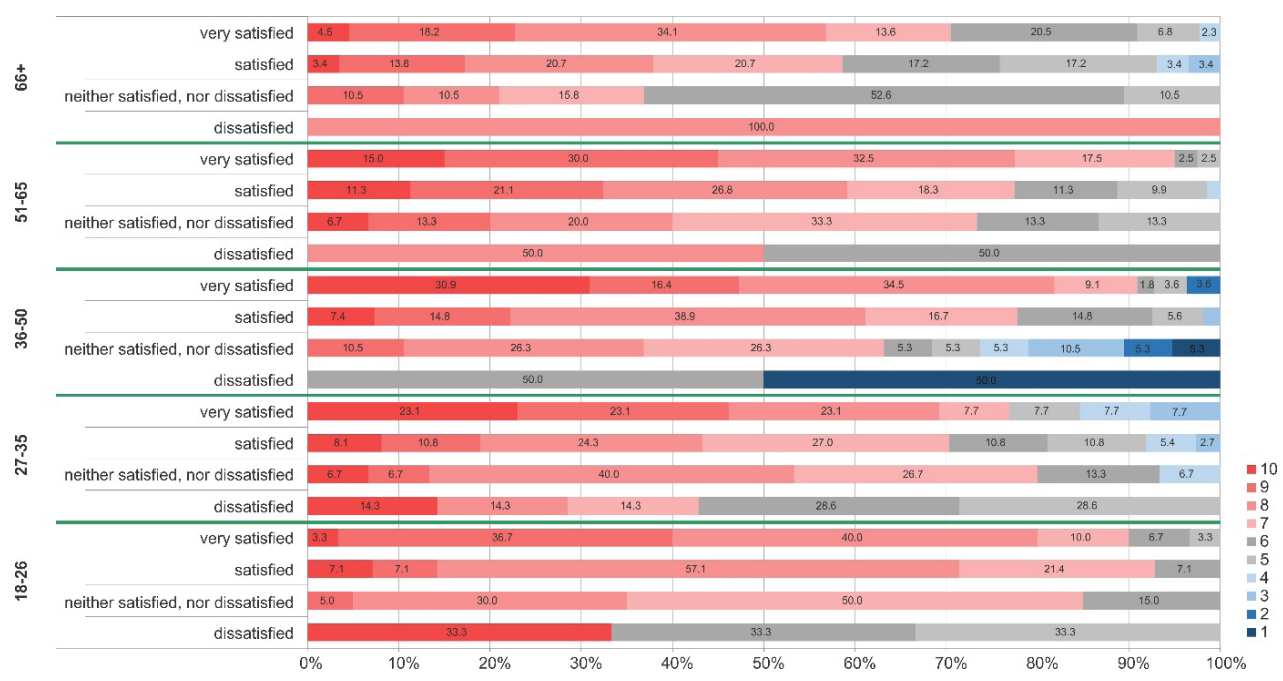

Fig. 10. Relationship between the quality of urban life and the quality of life by age group.

Note: There were no answers at the 'very dissatisfied ' pentile, as well as no 'zero' value in the scale from 0 to 10 for both men and women. 
surprising. In Figs 9 through 11, the quality of urban life is set by points, with quality of life ranging from 0 to 10 (however, the zero value didn't appear even once in 505 replies). There are differences between the quality of urban life and the quality of life in Liberec (Fig. 9) between men and women. For women, the quality of life at value 10 is a larger percentage of fairly dissatisfied than very satisfied with the quality of urban life. Men dissatisfied with the quality of urban life reported lower values of quality of life. Generally, however, for both men and women, the quality of life improves with the quality of urban life.

There are also differences for the quality of urban life and the quality of life by age group. The quality of life at the value of 10 is rated by 30.9 percent of very satisfied respondents between the ages 36 and 50 years, and 33.3 percent of fairly dissatisfied respondents are 18to 26-year-olds. The relationship of growing satisfaction with the quality of urban life in Liberec, with increasing quality of life of this city is the most remarkable in the age group $36-50$ years. Generally, the satisfaction with the quality of urban life as well as the quality of life of Liberec inhabitants increases with growing age. Extreme values of very dissatisfied in the age groups of 36-50 and 66 years and older are achieved thanks to the small population.

Because the value of the quality of urban life (Fig. 5) and quality of life (Fig. 8) increase with education gained, this is reflected also in relation to each other (Fig. 11). Here again, however, no direct causal connection applies, and so at all levels of education, the most satisfied with the quality of life out of people with primary education are those who are 'dissatisfied ' in the point group. Relatively extreme values in this pentile are again due to the small population.

To measure the intensity of the linear relationship between two variables - the quality of urban life and the quality of life - we used the Pearson correlation coefficient. We calculated it for the sex, age and education categories and it achieved positive values within all the

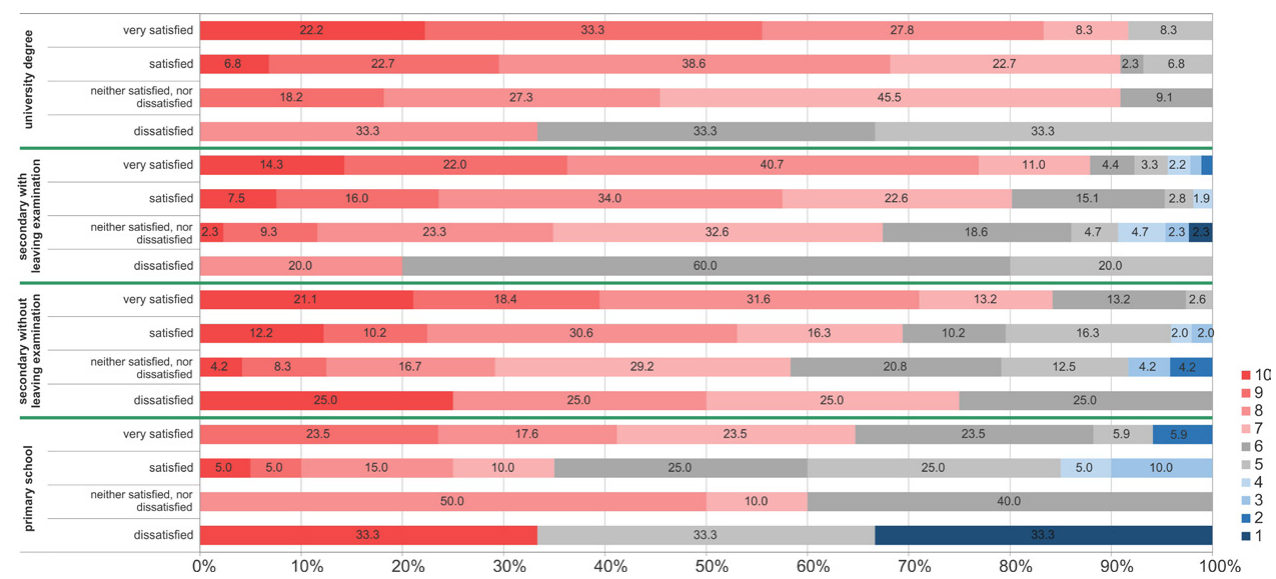

Fig. 11. Relationship between the quality of urban life and the quality of life by education.

Note: There were no answers at pentile 'very dissatisfied', as well as no ' null 'value in a scale from 0 to 10 for both men and women. 
categories. The coefficient reached the lowest and highest value within the age category. The predominant value is small, that is from 0.10 to 0.29 (de Vaus, 2002), and it was achieved in seven out of twelve categories. It is significant that the coefficients depending on sex, age and education differed significantly, as evidenced by the fact that the various groups of the population perceive the range between the quality of urban life and the quality of life differently (Table 2).

$\mathrm{T}$ a b l e 2. The difference between optimal and gained points between the quality of urban life and quality of life (by gender, age and education).

\begin{tabular}{|c|c|c|c|c|c|c|c|c|c|c|c|c|}
\hline \multicolumn{2}{|c|}{$\begin{array}{c}\text { The Quality of Urban Life - } \\
\text { Quality of Life }\end{array}$} & \multicolumn{2}{|c|}{ 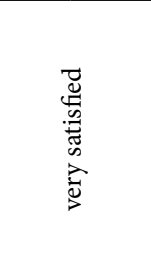 } & \multicolumn{2}{|c|}{ 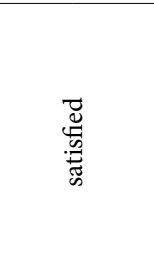 } & \multicolumn{2}{|c|}{ 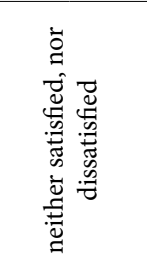 } & \multicolumn{2}{|c|}{ 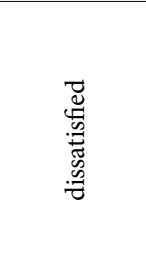 } & \multicolumn{2}{|c|}{ 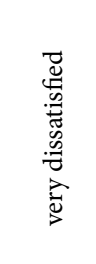 } & $\begin{array}{c}\text { Sum } \\
\pm \\
\text { (absolute } \\
\text { value) }\end{array}$ \\
\hline \multicolumn{2}{|c|}{$\begin{array}{c}\text { The optimal points (The Qual- } \\
\text { ity of Urban Life) }\end{array}$} & \multicolumn{2}{|c|}{$9-10$} & \multicolumn{2}{|c|}{$7-8$} & \multicolumn{2}{|c|}{$5-6$} & \multicolumn{2}{|c|}{$3-4$} & \multicolumn{2}{|c|}{$0-2$} & \\
\hline \multicolumn{2}{|c|}{$\begin{array}{l}\text { Points obtained (in Quality } \\
\text { of Life) } \\
\pm \text { difference from the optimal } \\
\text { points }\end{array}$} & pts. & \pm & pts. & \pm & pts. & \pm & pts. & - & pts. & \pm & \\
\hline \multirow{2}{*}{ Sex } & female & 8.10 & -0.90 & 7.49 & 0.49 & 7.02 & 2.02 & 6.90 & 3.90 & - & - & 7.31 \\
\hline & male & 7.93 & -1.07 & 7.43 & 0.43 & 6.72 & 1.72 & 5.60 & 2.60 & - & - & 5.82 \\
\hline \multirow{5}{*}{ Age } & $66+$ & 7.43 & -1.57 & 6.83 & -0.17 & 6.58 & 1.58 & 8.00 & 5.00 & - & - & 8.32 \\
\hline & $51-65$ & 8.30 & -0.70 & 7.68 & 0.68 & 7.27 & 2.27 & 7.00 & 4.00 & - & - & 7.65 \\
\hline & $36-50$ & 8.33 & -0.67 & 7.57 & 0.57 & 6.16 & 1.16 & 3.50 & 0.50 & - & - & 2.90 \\
\hline & $27-35$ & 7.69 & -1.31 & 7.11 & 0.11 & 7.40 & 2.40 & 6.71 & 3.71 & - & - & 7.53 \\
\hline & $18-26$ & 8.10 & -0.90 & 7.86 & 0.86 & 7.25 & 2.25 & 7.00 & 4.00 & - & - & 8.01 \\
\hline \multirow{4}{*}{$\begin{array}{l}\text { Educa- } \\
\text { tion }\end{array}$} & university degree & 8.44 & -0.56 & 7.89 & 0.89 & 7.55 & 2.55 & 6.33 & 3.33 & - & - & 7.33 \\
\hline & $\begin{array}{l}\text { secondary with } \\
\text { exam }\end{array}$ & 8.00 & -1.00 & 7.62 & 0.62 & 6.84 & 1.84 & 6.20 & 3.20 & - & - & 6.66 \\
\hline & $\begin{array}{l}\text { secondary without } \\
\text { exam }\end{array}$ & 8.13 & -0.87 & 7.31 & 0.31 & 6.63 & 1.63 & 7.75 & 4.75 & - & - & 7.56 \\
\hline & primary school & 7.00 & -2.00 & 6.10 & -0.90 & 7.10 & 2.10 & 5.33 & 2.33 & - & - & 7.33 \\
\hline
\end{tabular}

Note: There were no answers in pentile 'very dissatisfied'. Negative values are written in bold numerals.

In addition to the Pearson correlation coefficient, we decided to express the relationship between the quality of urban life and the quality of life in other ways. In order to assess the relationship between these variables in more detail, we recalculated a percentage representation of the responses of individual categories into points. We considered the points of quality of urban life to be optimal and we compared them with points of quality of life, which were divided according to sex, age and education (Table 2). This can be illustrated by the example 
of women who answered the question of quality of urban life as "satisfied". We assumed that their replies to the questions of quality of life (0-10) would be in the range of 9 to 10 points of the quality of urban life. If these women perceived the quality of urban life and the quality of life almost identically, it would be the optimal situation. This case did not really occur. Therefore, we recalculated a percentage of the occurrence of responses of the quality of urban life within the variables such as gender, age and education. There could be cases where respondents perceived the quality of urban life as more positive than quality of life, and vice versa. From Table 2 it is clear that in all tested categories in which respondents answered the question of quality of urban life with 'very satisfied', they already perceived the quality of life (in the range from 0 to 10) slightly differently, meaning that they didn $>$ assign points 9 or 10 but lower values. Within respondents who answered 'satisfied', such a case was only in two categories, namely in the population $66+$ and in the population with basic education. In all categories, and within other answers to the quality of urban life, they rated quality of life (0-10 scale) as higher. Absolutely the smallest differences in the perception of the quality of urban life and the quality of life occurred in the response "very satisfied" and the category of 27- to 35-year olds (point difference 0.11 ). The optimal group within all inhabitants of city of Liberec, who answered the questions, is the category of 36- to 50-year olds. The summary difference in all response categories of quality of urban life is the lowest (reaching 2.90 points), on the contrary, the group with the highest absolute difference is 66 years and older (8.32 points).

\section{Implications for policy-makers and urbanists}

As mentioned, the quality of urban life is holistic and implies two dimensions - the personal, which comprises life satisfaction in a certain city, and the spatial, which comprises quality of place. External conditions create the quality of place for living a good life. The sketch conceptualization of the quality of urban life and its measurement in the example of the city of Liberec gives rise to the following implications for the policy-makers and urbanists:

The purpose of public administration, represented by policy-makers on all hierarchical levels, is good governance. Governance is good when it provides services to citizens. In the context of quality of life, it implies the creation and strengthening of already established good places as places for living a good life.

Due to urbanization, good places are mainly cities. Therefore, the quality of urban life should be the focus of all policy-makers and urbanists, who put most of their decisions into concrete form.

The impact of quality of place on quality of life of people in developed countries is generally not large; on the other hand, it is not insignificant (Murgaš, 2016b). Residents of these countries take a high level of personal, religious and political freedoms, social and medical services, education, housing, technical infrastructure and the environment for granted. It can be assumed that this sense of certainty results in the quality of place having a lower value for quality of life. Within the developing countries, there are significant differences in the above criteria. Therefore, people from countries with a lower level of development commute to work or move to countries with higher levels of development, and not the other way around. 
Policy-makers on a regional and local level but not on a state level have a greater importance for a specific city and its quality. Local policy-makers should initiate the creation and development of sustainable local partnerships to improve the quality of urban life. From the start, it is necessary to carry out a study describing the status, which can be reached on a city district level, including surveys of citizens' opinions on the development priorities in these city districts. A good example is the progress of the municipality of Liberec.

The experience of the elaboration of the material quality of life in the municipality of Liberec (Murgaš, 2016a) means that in addition to large urban interventions in cities in the form of revitalization of deprived urban areas or increasing its technical facilities, there are mainly minor urban interventions in the form of the planting trees and maintenance of green areas, playgrounds, leisure opportunities and so on, which improve life satisfaction in the city.

In the Czech Republic, as in other countries of Central and Eastern Europe, there is no tradition of moving for work several times in life, as in the USA. However, a new remarkable phenomenon is emerging. It is the effort of some cities to attract mainly young residents to move to their cities. Subsequently, the cities will have higher tax revenue. Cities with higher level of quality of place will undoubtedly have a competitive advantage in this case.

\section{Discussion}

According to our findings, we consider the most important fact that the inhabitants of Liberec are very satisfied with the quality of urban life in this city. This correlates with positive assessment of quality of life of citizens of other cities, as Prague (Heřmanová, 2012) or Bratislava (Ira, 2015). Almost eighty percent declared they are very or mostly satisfied. On the contrary, the number of fairly dissatisfied is three percent; very dissatisfied is not even one percent.

Since we wanted to compare the relationship of the quality of urban life in Liberec with the quality of life of the inhabitants of Liberec in a further analysis, we constructed complex pivot charts and calculated the Pearson correlation coefficient.

Other findings are as follows:

- Within the pentiles for all variables, the values in pentiles 'very or mostly satisfied significantly prevail over the pentiles 'very or mostly dissatisfied'.

- $\quad$ The difference between very or fairly satisfied men and women is small.

- The quality of life rises with age; the most satisfied are the oldest inhabitants of Liberec aged 66 years and over, the pentile 'mostly satisfied ' with the value of fifty percent in the age group of 51- to 65-year olds has the highest numerical value of all measurements of quality of urban life and the quality of life in Liberec.

- Within the quality of life measured according to education is an expected increase from the population with basic education to inhabitants with university education.

Two concepts raised from the above mentioned are as follows:

(i) The quality of urban life and quality of life are two different qualities.

(ii) The difference in the quality of urban life and quality of life by sex, age and education is relatively large, especially in the age-based groups (2.90 to 8.32).

The result from measuring the quality of urban life and the quality of life in Liberec is 
that the quality of urban life on a scale of 0 to 10 is 7.2 , the quality of life of the inhabitants of Liberec is 7.5 (males 7.4, females 7.6, Murgaš, 2016a) and within the quality of place, Liberec has a value of 6.41 (Murgaš, Klobučník, 2016b). If we want to compare these values with the average values of the Czech Republic, the average quality of urban life in Czech cities is not known; however, it is known that the average quality of life of the inhabitants in the Czech Republic is 6.2 and the average value of the quality of place in all Czech cities is 5.14.

\section{Conclusion}

The aim of this paper was to answer the question whether the quality of urban life exists as an original, separate part of the concept of quality of life, or whether only the quality of life or the well-being of a certain city exists.

If the quality of urban life exists, it is necessary to outline its conceptualization and measurement. It will also be necessary to examine the relationship between the quality of urban life in Liberec and the quality of life of its inhabitants. From the above, it will be possible to draw conclusions for policy-makers and urban planners.

In our opinion, the quality of urban life is the original quality of life. We derive its quality from the possibility to ask the question: 'How satisfied are you with living in the city $\mathrm{N}$ in general? ' and to measure the answers (Murgaš, 2016a). Besides that, it is also possible to ask the inhabitants of the city $\mathrm{N}$ the question: 'How satisfied are you with your life in general?' We quantify the answer to the first question 'well-being in the city $\mathrm{N}$ ' and the answer to the second question 'well-being generally'. The quality of urban life - in a certain city $\mathrm{N}$ - is equal in meaning to quality of life (in which case, it is applied to a certain city), and it is also divided into dimensions. We will get the holistic quality of urban life in the city $\mathrm{N}$ by connecting the well-being of inhabitants in the city $\mathrm{N}$ and quality of place in the city N. Measuring the quality of urban life in Liberec supports the claim about the existence of quality of urban life as a separate category of quality of life.

The conceptualization of quality of urban life is based on the following premises:

i. The city in terms of quality of life research is a place, the quality of urban life is the satisfaction with life in the city $\mathrm{N}$ and the quality of place within it. At the same time, the quality of urban life is a societal quality. This is a key element of its conceptualization.

ii. Quality of urban life is holistic; it consists of two dimensions: subjective (well-being) and objective (quality of place). In contrast to the quality of life, it has only one level - the societal level.

iii. A reference point to which the concept of quality of urban life relates is the concept of the good life, which is lived in a certain city as a good place.

iv. Even if well-being is more important out of the two dimensions, it is not a quality of urban life itself. The quality of urban life is semantically 'over' well-being and the quality of place, which are its dimensions.

v. Quality of life and quality of urban life are two notions and each means something else. Quality of life is the quality of life of the individual, and it is secondary to where the individual lives, whether in the city or village. 


\section{Acknowledgements}

We would like to express our very great appreciation to Mrs. Catherine Dimmock-Benko, external teacher at the Department of Languages, for her willingness to provide the linguistic correction of this paper. This article was funded by the Project SGS FP 21258 Technical University of Liberec.

\section{References}

Andráško, I. (2006). Percepcia kvality života v mestských štvrtiach Bratislavy. Geografická Revue, 2(2), $227-240$.

Andráško, I. (2007). Vnútorná štruktúra mesta z hladiska kvality života. Dizertačná práca, Geografický ústav SAV, Bratislava.

Andráško, I., Lesová, P., Kunc, J. \& Tonev P. (2013). Perception of quality of life in Brno housing estates. Hungarian Geographical Bulletin, 62(1), 90-101.

Andráško, I. (2016). Kvalita života v mestách. Brno: Masarykova univerzita.

Andrews, C.J. (2001). Analysing quality-of-place. Environment and Planning B: Planning and Design, 28, 201-217. DOI: 10.1068/b2714.

Blatný, M. \& Šolcová I. (2015). Well-being. In M. Blatný (Ed.), Personality and well-being across the life-span (pp. 20-59). Hampshire: Palgrave Macmillan. DOI: 10.1057/978-1-137-43996-3.

Bradley, B. (2015). Well-being. Cambridge: Polity Press.

Budowski, M., Schief, S. \& Sieber M. (2016). Precariousness and quality of life - a qualitative perspective on quality of life of households in precarious prosperity in Switzerland and Spain. Applied Research in Quality of Life, 11, 1035-1058. DOI: 10.1007/s11482-015-9418-7.

de Vaus, D. (2002). Surveys in social research. London: Routledge.

Ferris, A. (2010). Approaches to improving the quality of life. How to enhance the quality of life. Dordrecht: Springer.

Frick, D. \& Hoefert H.-W. (1986). The quality of urban life: Social, psychological, and physical conditions. Berlin: De Gruyter.

Heřmanová, E. (2012). Koncepty, teorie a měření kvality života. Praha: Sociologické nakladatelství.

Ira, V. (2005). Quality of life and urban space (case studies from city of Bratislava, Slovakia). Europa XXI, 12, 83-96.

Ira, V., Michálek, A. \& Podolák P. (2005). Kvalita života a jej regionálna diferenciácia v Slovenskej republike. Životné Prostredie, 39(6), 290-294.

Ira, V. \& Šuška P. (2006). Percepcia kvality života v mestskom prostredí (na príklade mesta Partizánske). Geografická Revue, 2, 309-332.

Ira, V. \& Andráško I. (2008). Quality of life in the urban environment of Bratislava: two time-spatial perspectives. Geografický Časopis, 60, 149-178.

Ira, V. (2015). Petržalka a kvalita života jej obyvatel’ov (subjektívna dimenzia hodnotenia). Životné Prostredie, $49(2), 82-86$.

Izakovičová, Z. (2005). Example of the elaboration of the strategy of sustainable development. Ekológia (Bratislava), 24(3), 277-291.

Izakovičová, Z., Mederly, P. \& Petrovič F. (2017). Long-term land use changes driven by urbanisation and their environmental effects (example of Trnava City, Slovakia). Sustainability, 9(9), 1553. DOI: 10.3390/su9091553.

Kladivo, P. \& Halás M. (2012). Quality of life in an urban environment: A typology of urban units of Olomouc. Quaestiones Geographicae, 31(2), 49-60. DOI: 10.2478/v10117-012-0018-4.

Landry, Ch. (2008). The creative city: A toolkit for urban innovators. New York: Earthscan.

Marans, R. \& Kweon B.-S. (2011). The quality of life in metro Detroit at the beginning of the millennium. In R.W. Marans \& R. Stimson (Eds.), Investigating quality of urban life. Theory, methods, and empirical research (pp. 163-183). Dordrecht: Springer. DOI: 10.1007/978-94-007-1742-8_7.

Marans, R.W. \& Stimson R. (2011). Challenges for quality of urban life research. In R.W. Marans \& R. Stimson (Eds.), Investigating quality of urban life. Theory, methods, and empirical research (pp. 437-444). Dordrecht: Springer. DOI: 10.1007/978-94-007-1742-8_19.

Marans, R.W. (2012). Quality of urban life studies: An overview and implications for environment-behaviour research. Procedia - Social and Behavioral Sciences, 35, 9-22. DOI: 10.1016/j.sbspro.2012.02.058.

Marans, R.W. (2015). Quality of urban life \& environmental sustainability studies: Future linkage opportunities. Habitat International, 45, 47-52. DOI: 10.1016/j.habitatint.2014.06.019. 
Michalos, A.C. \& Robinson S.R. (2012). The good life: Eighth century to third century BCE. In K.C. Land, A.C. Michalos \& M.J. Sirgy (Eds.), Handbook of social indicators and quality of life research (pp. 23-62). Dordrecht: Springer. DOI: 10.1007/978-94-007-2421-1.

Murgaš, F. \& Böhm H. (2015). Does economic growth improve quality of life? In $15^{\text {th }}$ International Multidisciplinary Scientific GeoConference SGEM 2015 (pp. 213-220). Albena, Bulgaria, 2014. Ecology, Economics, Education and Legislation. Conference Proceedings, vol. III.

Murgaš, F. (2016a). Quality of life in the municipality Liberec (in Czech). Liberec: Technická univerzita.

Murgaš, F. (2016b). Geographical conceptualization of quality of life. Ekológia (Bratislava), 35(4), 309-319. DOI: 10.1515/eko-2016-0025.

Murgaš, F. \& Klobučník M. (2016a). Municipalities and regions as good places to live: Index of quality of life in the Czech Republic. Applied Research in Quality Life, 11(2), 553-570. DOI: 10.1007/s11482-014-9381-8.

Murgaš, F. \& Klobučník M. (2016b). Does the quality of a place affect well-being? Ekológia (Bratislava), 35(3), 224-239. DOI: 10.1515/eko-2016-0018.

Nuvolati, G. (2014). Quality of urban life. In A.C. Michalos (Ed.), Encyclopedia of quality of life and well-being research (pp. 6848-6850). Dordrecht: Springer.

Pacione, M. (2003a). Urban environmental quality and human wellbeing - a social geographical perspective. Landsc. Urban Plann., 65, 19-30. DOI: 10.1016/S0169-2046(02)00234-7.

Pacione, M. (2003b). Quality of life research in urban geography. Urban Geography, 24(4), 314-339. DOI: 10.2747/0272-3638.24.4.314.

Peil, M. (1984). African urban life: Components of satisfaction in Sierra Leone. Social Indicators Research, 14(3), 363-384. DOI: 10.1007/BF00692990.

Podzimek, M. (2016). The crisis of effectiveness of education in postmodern age. In SGEM 2016 (pp. 1069-1074). Book 1 Psychology and Psychiatry, Sociology and Healthcare, Education. Conference Proceedings, vol. III. Albena, Bulgaria, August 24-30, 2016.

Psatha, E., Deffner, A. \& Psycharis Y. (2011). Defining the quality of urban life: Which factors should be considered? European Regional Science Association, 51st European Congress Barcelona. Available http://www-sre.wu.ac.at/ ersa/ersaconfs/ersa11/e110830aFi nal00785.pdf

Rapley, M. (2008). Quality of life research. A critical introduction. London: SAGE.

Rezvani, M.R., Mansourian, H. \& Sattari M.H. (2013). Evaluating quality of life in urban areas (Case study: Noorabad City, Iran). Social Indicators Research, 112(1), 203-220. DOI: 10.1007/s11205-012-0048-2.

Rišová, K. \& Pouš R. (2018). Urban facilities in the quality of life research: a case study of Banská Bystrica city (Central Slovakia). Geografický Časopis, 70, 99-116.

Ruiz, L.Z. (2015). Qualitative studies of young people's quality of life in urban and rural areas. In G. Tonon (Ed.), Qualitative studies in quality of life (pp. 149-178). Dordrecht: Springer.

Santos, L.D. \& Martins I. (2007). Monitoring urban quality of life: the Porto Experience. Social Indicators Research, 80, 411-425. DOI: $10.1007 / \mathrm{s} 11205-006-0002-2$.

Sirgy, J.M. (2012). The psychology of quality of life. Hedonic well-being, life satisfaction, and eudaimonia. Dordrecht: Springer.

Stimson, R., McCrea, R. \& Western J. (2011). The Brisbane South East Queensland region, Australia: Subjective assessment of quality of urban life and changes over time. In R.W. Marans \& R. Stimson (Eds.), Investigating quality of urban life. Theory, methods, and empirical research (pp. 185-207). Dordrecht: Springer. DOI: 10.1007/97894-007-1742-8_8.

Tiran, J. (2016). Measuring urban quality of life: case study of Ljubljana. Acta Geographica Slovenica, 56(1), 57-73. DOI: $10.3986 /$ ags.828.

Türkoğlu, H., Bölen, F., Baran, P.K. \& Terzi F. (2011). Measuring quality life in Istanbul. In R.W. Marans \& R. Stimson (Eds.), Investigating quality of urban life. Theory, methods, and empirical research (pp. 209-231). Dordrecht: Springer. DOI: 10.1007/978-94-007-1742-8_9.

Veenhoven, R. (2013). Notions of the good life. In S.A. David, I. Boniwell \& A. Conley Ayers (Eds.). The Oxford handbook of happiness (pp. 161-173). Oxford: Oxford University Press.

Veenhoven, R. (2014). Quality of life, an overview. In A.C. Michalos (Ed.), Encyclopedia of quality of life and wellbeing research (pp. 5265-5269). Dordrecht: Springer. DOI: 10.1007/978-94-007-0753-5.

Włodarczyk, K. (2015). Quality of urban life in Poland. Journal of International Studies, 8(2), 155-163. DOI: $10.14254 / 2071-8330.2015 / 8-2 / 13$. 